Original Research Paper

\title{
Optimalisasi Pemanfaatan Limbah Plastik dan Limbah Rumah Tangga Dalam Upaya Penerapan Zero Waste di Desa Pengadang
}

\author{
Nisa Rahmadania Erlan ${ }^{1}$, Sukmadi Farid Sabri ${ }^{2}$, Rizandi Mahendra ${ }^{3}$, Eliza Mawarti ${ }^{4}$, Sania $^{5}$, Nina Tunmi \\ Nur Amalia ${ }^{7}$, Tazkiya Aulia Rachman ${ }^{8}$, M. Dhava Estiwan', Hasanul Falah Putra Junaidy ${ }^{10}$, DioYudha \\ Prawira Bakary ${ }^{11}$, Nuriadi ${ }^{12 *}$ \\ 1 Program Studi Farmasi Fakultas Kedokteran Universitas Mataram, \\ ${ }^{2}$ Program Studi Ilmu Hukum Fakultas Hukum Universitas Mataram, \\ ${ }^{3}$ Program Studi Peternakan Fakultas Peternakan Universitas Mataram, \\ ${ }^{4}$ Program Studi Peternakan Fakultas Peternakan Universitas Mataram, \\ ${ }^{5}$ Program Studi Ilmu Ekonomi Studi Pembangunan (IESP) Fakultas Ekonomi dan Bisnis Universitas Mataram, \\ ${ }^{6}$ Program Studi Kimia Fakultas Matematika dan Ilmu Pengetahuan Alam (MIPA) Universitas Mataram, \\ ${ }^{7}$ Program Studi Agroekoteknologi Fakultas Pertanian Universitas Mataram, \\ ${ }^{8}$ Program Studi Teknik Informatika Fakultas Teknik Universitas Mataram, \\ ${ }^{9}$ Program Studi Ilmu Ekonomi Studi Pembangunan (IESP) Fakultas Ekonomi dan Bisnis Universitas Mataram, \\ ${ }^{10}$ Program Studi Teknik Informatika Fakultas Teknik Universitas Mataram, \\ ${ }^{11}$ Program Studi Teknik Elektro Fakultas Teknik Universitas Mataram, \\ ${ }^{12}$ Universitas Mataram, Mataram, Indonesia
}

https://doi.org/10.29303/jpmpi.v3i2.1450

Sitasi: Erlan, N. R., Sabri, S. F., Mahendra, R., Mawarti, E., Sania., Tunmi, N., Amalia, N., Rachman, T. A., Estiwan, M. D., Junaidy, H. F. P., Bakary, D. Y. P \& Nuriadi. (2022). Optimalisasi Pemanfaatan Limbah Plastik dan Limbah Rumah Tangga Dalam Upaya Penerapan Zero Waste di Desa Pengadang. Jurnal Pengabdian Magister Pendidikan IPA, 5(1).

Article history

Received: 21 Januari 2022

Revised: 30 Januari 2022

Accepted: 27 Februari 2022

*Corresponding Author:

Nuriadi ,Universitas Mataram,

Mataram, Indonesia;

Email:

nuriadi@unram.ac.id
Abstrak: Kuliah kerja nyata (KKN) merupakan salah satu bentuk wujud implementasi dari Tri Dharma perguruan tinggi yaitu kewajiban perguruan tinggi untuk melaksanakan pendidikan, pengajar, penelitian serta pengabdian kepada masyarakat. Mahasiswa mempunyai peran strategis sebagai agent of change (agen perubahan). KKN merupakan mata kuliah wajib yang harus ditempuh diperguruan tinggi Universitas Mataram yang memiliki tujuan yaitu melalui keterlibatan mahasiswa di dalam mengindentifikasi, merumuskan serta memecahkan masalah yang ada dalam masyarakat. Salah satu masalah dalam masyarakat yaitu sampah maka diambil tema tentang Zero Waste. Zero Waste merupakan suatu upaya konservasi sumber daya yang melibatkan produksi, konsumsi, penggunaan kembali, dan pemulihan produk hingga kemasannya, zerowaste juga, merupakan filsafat yang mendorong daur ulang sumber daya, dari system linier menuju siklus tertutup, sehingga semua produk digunakan Kembali. Kelompok Mahasiswa KKN UNRAM memiliki misi untuk menjadikan Masyarakat Desa Pengadang Kecamatan Praya Tengah Kabupaten Lombok Tengah menerapkan upaya bebas sampah diharapkan dapat mengeliminasi sampah yang dapat menjadi ancaman bagi kesehatan manusia, alam, hewan, maupun bumi kita ini melalui program kerja terkait Zero Waste.Beberapa kegiatan yang dilakukan yaitu sosialisasi pembuatan eco enzyme dari sampah dapur, sosialisasi tentang zero waste, biopori, penanaman bibit pohon dan pembuatan ecobrick dari sampah-sampah plastik. Hasilnya diharapkan masyarakat lebih peduli dengan kebersihan lingkungan sekitar dengan tidak membuang sampah sembarangan dan bisa memanfaatkan sampah yang tidak bernilai menjadi bernilai jual tinggi sehingga lingkungan masyarakat bisa terhindar dari sampah dan perekonomian masyarakat setempat lebih baik.

Kata kunci: zero waste, sosialisasi, ecobrick, eco enzyme, biopori 


\section{Pendahuluan}

\section{Program Kuliah Kerja Nyata (KKN)}

merupakan salah satu bentuk wujud implementasi dari Tri Dharma Perguruan Tinggi, yaitu kewajiban perguruan tinggi untuk melaksanakan pendidikan, pengajaran, penelitian serta pengabdian kepada masyarkat. Secara khusus, KKN termasuk ke bagian pengabdian kepada masyarakat yang di mana mahasiwa dapat mengaplikasikan ilmu yang diperoleh selama perkuliahan untuk dipergunakan di tengah-tengah masyarakat secara langsung. KKN merupaan mata kuliah wajib yang harus ditempuh di Perguruan Tinggi Universitas Mataram yang memiliki tujuan yaitu, melalui keterlibatan mahasiwa di dalam masayarkat diharapkan mampu menemukan, mengidentifikasi, merumuskan serta memecahkan permasalahan yang terdapat dalam masyarakat. Hal ini diharapkan dapat memicu kemampuan masyarakat dalam mengembangkan diri dan wilayah sehingga kesejahteraan meningkat. Salah satu desa yang menjadi mitra kerja sama oleh Universitas Mataram untuk menjadi tujuan pelaksanaan KKN ini adalah Desa Pengadang.

Desa Pengadang merupakan desa yang terletak di Kecamata Praya Tengah, Kabupaten Lombok Tengah. Berdasarkan data statistik dan spasial Kecamatan Praya Tengah tahun 2019 luas wilayah Desa Pengadang adalah $8,14 \mathrm{~km}^{2}$ dengan persentase 9,31\%. Desa Pengadang terdiri dari 17 lingkungan dan memiliki penduduk sebanyak 9.600 jiwa. Desa ini merupakan salah satu desa yang sektor lingkunganya terdampak pencemaran lingkungan akibat tidak adanya Tempat Pembuangan Akhir (TPA). Sehingga banyak sampah yang dapat ditemukan di pinggir jalan. Hal ini sangat berpengaruh terhadap kualitas kesehatan dan pencemaran lingkungan yang akan mengakibatkan penumpukan sampah. Permasalahan sampah hasil kegiatan rumah tangga ini oleh perangkat desa telah berusaha untuk diatasi dengan adanya petugas sampah yang ditugaskan mengangkut sampah dari setiap rumah warga desa. Namun hal ini belum juga dapat terselenggara dengan baik sebab sering adanya keterlambatan pengangkutan sampah dan kurangnya petugas, sehingga terjadi penumpukan sampah.

Berdasarkan permasalah tersebut, maka diperlukan suatu inovasi supaya sampah-sampah bisa dikurangi dan didaur ulang sehingga dapat dimanfaatkan kembali. Oleh karena itu kelompok KKN berusaha untuk menciptakan sebuah inovassi untuk mengatasi masalah tersebut. Dalam menangani sampah organik maupun anorganik, kelompok KKN yang bertema Zero Waste menawarkan cara untuk mengolah sampah organik menjadi pupuk serta sampah anorganik menjadi kerajinan dan ecobrick yang bermanfaat bagi masyarakat.

Tujuan dari kegiatan tersebut yaitu: (1) Mengurangi penggunaan sampah di Desa Pengadang, (2) meningkatkan pemahaman masyarakat tentang pengelolaan sampah di rumah, (3) pemanfaatan sampah rumah tangga maupun sampah pedagang sebagai bahan pembuatan eco eznyme, (4) pembuatan lubang biopori sampah rumah tangga sebagai tempat pembuangan akhir, (5) dan pembuatan kursi dari ecobrick berbahan plastik dan botol bekas yang sulit terurai oleh tanah.

\section{Metode}

Metode pelaksanaan yang dilakukan mahasiswa Kuliah Kerja Nyata (KKN) Universitas Mataram ini terbagi menjadi beberapa bagian yaitu:

1) Metode observasi

Metode observasi adalah bentuk pengamatan yang dilakukan oleh para mahasiswa KKN di desa pengadang untuk mendapatkan gambaran kondisi masyarakat. Secara keseluruhan dan dapat menggali masalah secara spesifik dan riil yang dihadapi oleh masyarakat yang ada di desa Pengadang dengan sistematis. Pada metode ini, penulis terjun langsung untuk mengamati secara langsung terhadap keadaan nyata yang ada didesa yang juga berhubungan dengan zero waste, pelaksanaan $\mathrm{KKN}$, kegiatan-kegiatan dan fenomena sosial yang terjadi sebagai dampak dari adanya pelaksanaan KKN yang diterapkan. Data yang diperlukan dalam metode ini adalah mengamati secara langsung di lokasi yaitu desa Pengadang.

2) Metode interview (wawancara)

Metode interview adalah metode pengumpulan data melalui tanya jawab secara langsung dengan narasumber data untuk memperoleh informasi yang diinginkan. Interview atau wawancara ini dilakukan dengan mengajukan pertanyaan secara lisan kepada narasumber dengan kontak langsung atau tatap muka. Wawancara ini dilakukan oleh peneliti terhadap informan atau narasumber yang menjadi objek penelitian yaitu KADUS, PKK, PEMDES, dan BUMBDES dan juga Karang Taruna Desa Pengadang. Wawancara ini bertujuan untuk memperoleh informasi yang berhubungan dengan pokok persoalan penelitian yaitu kerja sama antara mahasiswa dengan KADUS, PEMDES DAN BUMDES, PKK dan Karang Taruna yang ada di Desa Pengadang.

3) Metode Dokumentasi

Metode dokumentasi adalah pegumpulan data dengan cara mencatat data penelitian yang terdapat dalam buku-buku catatan, arsip dan lain sebagainya. Data-data yang digunakan yaitu data yang berhubungan dengan penelitian seperti profil desa, dokumen-dokumen mengenai pengelolaan sampah dan lain sebagainya. 
Adapun seluruh rangkaian kegiatan ini dilakukan melalui tiga tahapan yaitu:

\section{1) Tahapan persiapan}

Sebelum memulai kegiatan KKN, disiapkan terlebih dahulu surat pengantar KKN serta izin kepada kepala desa untuk melakukan kegiatan KKN di Desa Pengadang. Secara umum program wajib yang akan dilaksanakan oleh mahasiswa selama KKN yaitu program Kerja ecobrick. dengan adanya program tersebut diharapkan bisa memberikan manfaat bagi desa dan masyarakat sekitar.

2) Sosialisasi program

Kegiatan sosialisasi yang dilakukan ditargetkan kepada seluruh masyarakat. pada kegiatan ini akan dijelaskan maksud dan tujuan aktivitas dan memperkenalkan metode serta media apa saja yang digunakan pada kegiatan tersebut. contohnya brosur serta spanduk kegiatan.

3) Evaluasi dan monitoring

Penilaian diakhir kegiatan dilakukan untuk melihat pencapaian dari program yang telah dilaksanakan untuk mengukur atau mengetahui keberhasilan, meningkatkan efetivitas, pengaruh dari kegiatan tersebut dan sebagai acuan untuk perbaikan kedepan. Monitoring dilakukan dengan cara mengecek atau memeriksa apakah program utama pada kegiatan KKN tersebut berjalan atau tidak dengan cara berkunjung langsung ke desa.

\section{Hasil dan Pembahasan}

Kegiatan terkait strategi pengelolaan sampah yang terlaksana yaitu, Sosialisasi mengenai eco eznyme. Pada sosialisasi tentang eco eznyme mahasiswa KKN UNRAM turut serta menganjak pemateri dari Portir Indonesia internasional. Sosialisasi ini dilakukan dalam dua tahapan yaitu tahap pertama, akan menjelaskan manfaat dari eco eznyme dan mencontohkan cara pembuatan eco eznyme. Menurut rambe (2021) Pembuatan produk ini hanya membutuhkan air, gula (gula merah, molasses) sebagai sumber karbon, serta sampah organik sayur dan buah. Dalam pengolahan eco eznyme sampah yang dapat digunakan hanya sebatas sampah organik. Produk eco eznyme merupakan produk ramah lingkungan yang sangat fungsional, mudah digunakan, dan mudah dibuat. Setiap orang dapat membuat produk ini dengan mudah. Bahan-bahan yang digunakan pun sederhana dan banyak tersedia di sekitar kita. Dan pada tahap kedua, akan melakukan diskusi dan tanya jawab, pada tahap kedua ini pemateri dari Portir Indonesia Internasional akan menjawab pertanyaan yang diajukan oleh peserta. Dalam sosialisasi mengenai eco eznyme juga menjelaskan bagaimana mengolah sampah plastik menjadi ecobrick yang selanjutnya dapat dijadikan kursi dan menjelaskan kegunaan pembuatan lubang biopori.
Selain kegiatan sosialisasi mengenai eco enzyme, kegiatan lain yang dilakukan yaitu memberikan sosialisasi tentang lubang biopori. Adapun yang dimaksud dengan lubang resapan biopori. Menurut Keruniastuti (2014) bipori adalah lubang silindris yang dapat dibuat secara vertical ke dalam tanah dengan diameter berkisar antara 10-30 cm, dan kedalaman sekitar $100 \mathrm{~cm}$ atau tidak melebihi kedalaman muka air tanah. Selanjutnya lubang biopori dapat diisi dengan sampah organic yang dapat berfungsi sebagai menghipkan mikroorganisme tanah. Mikroorganisme di dalam tanah ini yang dapat membentuk terowongan atau pori-pori di dalam tanah sehingga dapat mempercepat resapan air di dalam tanah secara horizontal

Mahasiswa KKN UNRAM juga melakukan penyuluhan tentang pembuatan ecobrick yang dapat dijadikan kursi. Fungsi dari ecobrick sendiri yaitu bukan untuk mengurai sampah yang terdapat pada botol tetapi untuk memperpanjang umur sampah plastik di dalam botol. Pembuatan ecobrick merupakan solusi untuk menagani sampah plastik. Pada penyuluhan ecobrick mahasiswa KKN UNRAM turut serta mengajak anakanak untuk ikut dalam pembuatan ecobrick. KKN mahasiswa unram mengajarkan kepada anak-anak untuk memasukan sampah plastik yang sudah kering ke dalam botol hingga padat. Sehingga jika semua botol plastik sudah terisi dengan sampah plastik. Selanjutnnya mahasiswa KKN UNRAM menyusun botol botol yang telah terisi sampah plastik untuk dapat dijadikan kursi. Tujuan mahasiswa KKN UNRAM mengajak anak-anak untuk ikut serta yaitu untuk memacu kesadaran terhadap anak-anak sehingga tidak membuang sampah plastik sembarangan yang dapat dijadikan ecobrick seperti kursi yang bernilai ekonomis dan agar dapat lebih mencintai lingkungannya.

A. Sosialisasi Program Kerja

Sosialisasi program kerja bertujuan untuk menginformasikan kepada masyarakat mengenai program-program kerja yang akan dilaksanakan di Desa Pengadang. Dalam pelaksanaannya masyarakat diberikan penjelasan mengenai program utama maupun program tambahan kepada Kepala Desa, kepala dusun, maupun masyarakat mengenai kegiatan yang akan dijalankan di Desa Pengadang mulai dari tujuan dibuatnya program kerja tersebut hingga manfaatnya kepada masyarakat.

Sosialisasi yang berlokasi di Kantor Desa Pengadang tersebut dihadiri oleh Kepala Desa, Kepala Dusun se-Desa Pengadang, Dosen Pembimbing Lapangan, tokoh masyarakat, staf kantor desa, serta seluruh anggota KKN. Sehingga dalam pelaksanaannya ketua KKN Tematik Unram melakukan persentasi terkait program kerja yang dilaksanakan.

Adapun hambatan yang kami temui pada saat melaksanakan acara ini yaitu pada saat pengumpulan warga dalam acara sosialisasi cukup sulit mengingat 
sebagian besar warga adalah petani sehingga pada saat acara diadakannya warga sedang pergi bertani. Sebagai solusinya kami mengundang petinggi-petinggi di masyarakat dengan mendatangi rumahnya. Dengan bergitu, sosialisasi dapat berjalan dengan lancar sesuai yang diharapkan.

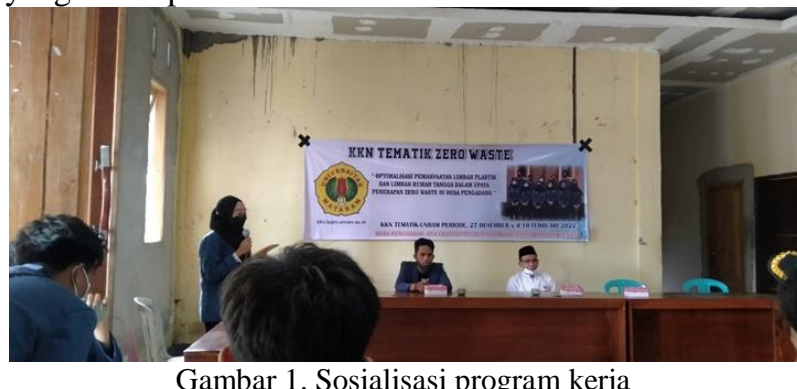

\section{B. Ecobrick}

Program Ecobrick merupakan program yang bertujuan untuk mengajak masyarakat untuk mengurangi, menggunakan kembali dan mendaur ulang sampah dengan cara memenjarakan sampah kresek didalam botol. Botol yang sudah terisi sampah plastik sampai padat dapat digunakan untuk membuat berbagai hal diantaranya kursi dan meja. Dalam program kerja ini kami melakukan sosialisasi kepada para anak-anak di Desa Pengadang dan mengajak anak-anak tersebut mengumpulkan sampah plastik dan memasukannya ke dalam botol plastik. Hasil dari ecobrick tersebut kami rakit menjadi kursi yang mempunyai nilai yang tinggi.

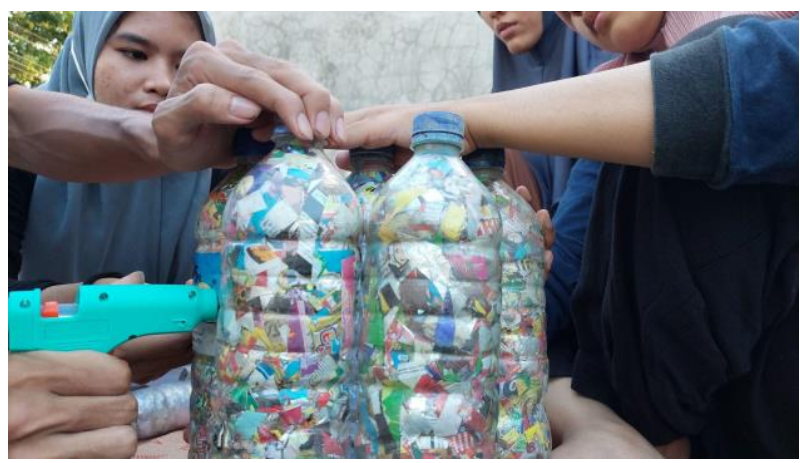

Gambar 2. Menyatukan ecobrick untuk dijadikan kursi

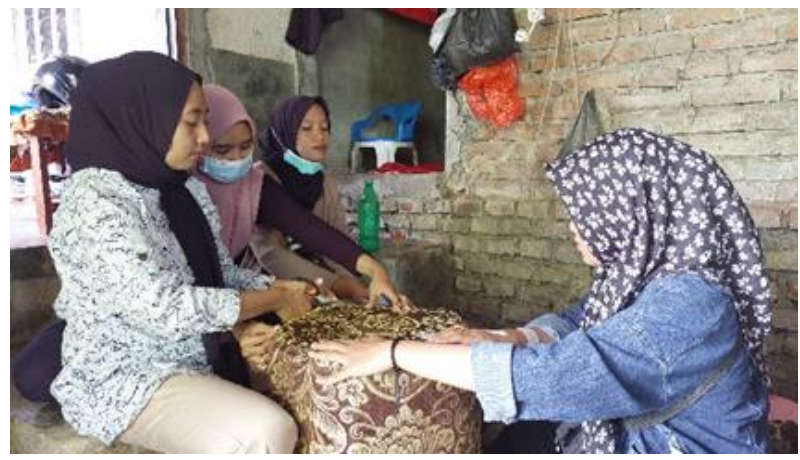

Gambar 3. Pemasangan busa dan kain untuk lapis kursi ecobrick

\section{Eco Eznyme}

Program eco enzyme ini dilakukan dengan membuat sendiri eco enzyme dan melakukan sosialisasi di kantor desa Pengadang dengan bekerja sama sama dengan Portir International Indonesia. Program ini merupakan program yang bertujuan untuk mengajak masyarakat untuk mengembalikan ekosistem lingkungan sebagaimana mestinya dengan cara membuat larutan campuran antara larutan molase dengan sisa-sisa buahbuuahan dan sayur-sayuran yang masih segar serta air sumur ataupun hujan dan didiamkan dalam kurun waktu kurang lebih 3 bulan. Larutan inilah yang digununakan untuk menyiram tanaman ataupun dituangkan langsung dalam parit di sekitar Desa Pengadang.

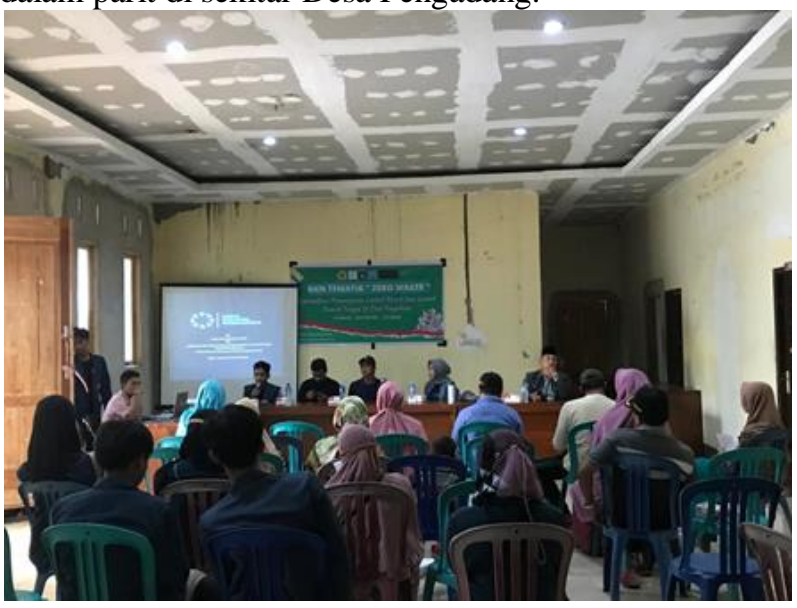

Gambar 4. Sosialisasi pembuatan eco enzyme

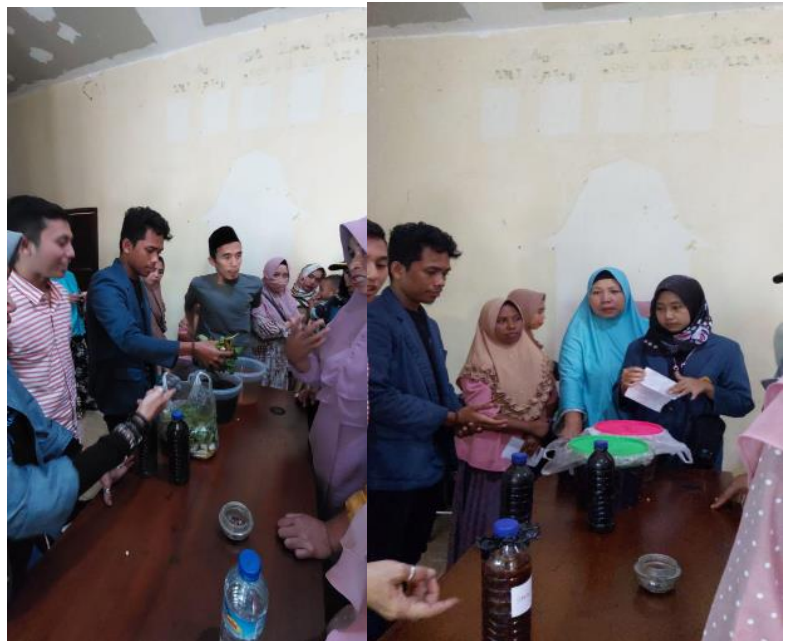

Gambar 5. Demo pembuatan eco eznyme

\section{Lubang Biopori}

Lubang resapan biopori adalah lubang silindris yang dibuat secara vertikal ke dalam tanah sebagai metode resapan air yang ditujukan untuk mengatasi genangan air dengan cara meningkatkan daya resap air pada tanah. Metode ini dicetuskan oleh Dr. Kamir Raziudin Brata, salah satu peneliti dari Departemen Ilmu 
Tanah dan Sumberdaya Lahan, Fakultas Pertanian Institut Pertanian Bogor. Resapan air diubah jadi penampungan sampah organic. Program kerja ini dilakukan dengan menggali lubang menggunakan alat bor di dusun-dusun yang ada di Desa Pengadang.

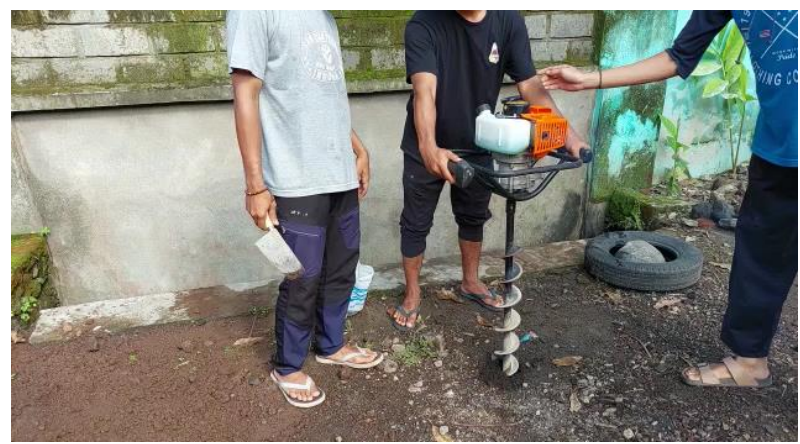

Gambar 6. Pembuatan lubang biopori

Selain pelaksanaan program kerja utama untuk desa, mahasiswa KKN UNRAM juga memiliki program kerja tambahan dan mengikuti berbagai kegiatan bersamawarga desa. Berikut dilampirkan dokumentasi kegiatan program KKN Tematik Zero Waste yang belokasi di Desa Pengadang, Kecamatan Praya Tengah, Kabupaten Lombok Tengah.

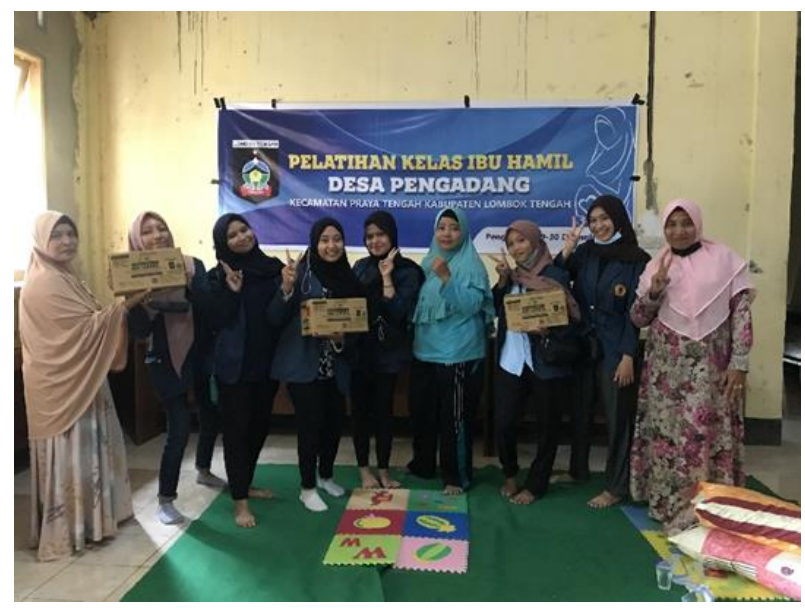

Gambar 7. Meramaikan pelatihan kelas ibu hamil

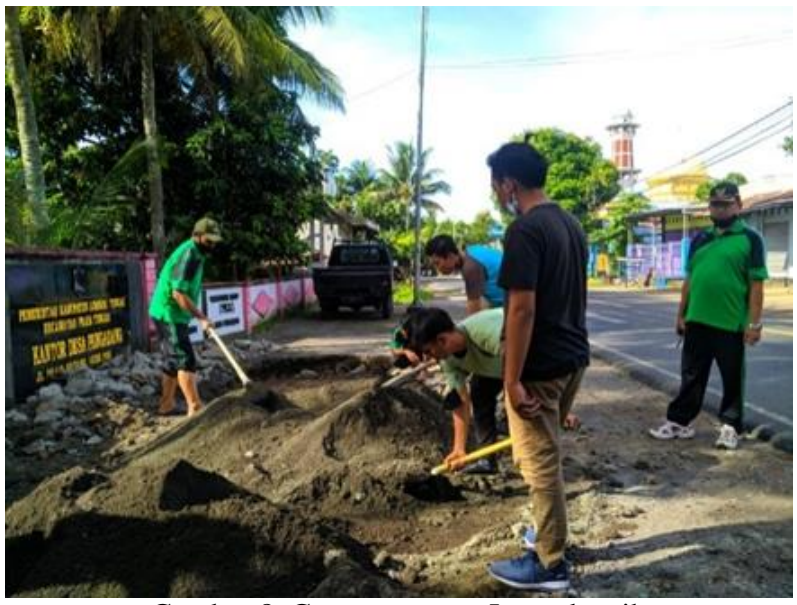

Gambar 8. Gotong royong Jumat bersih

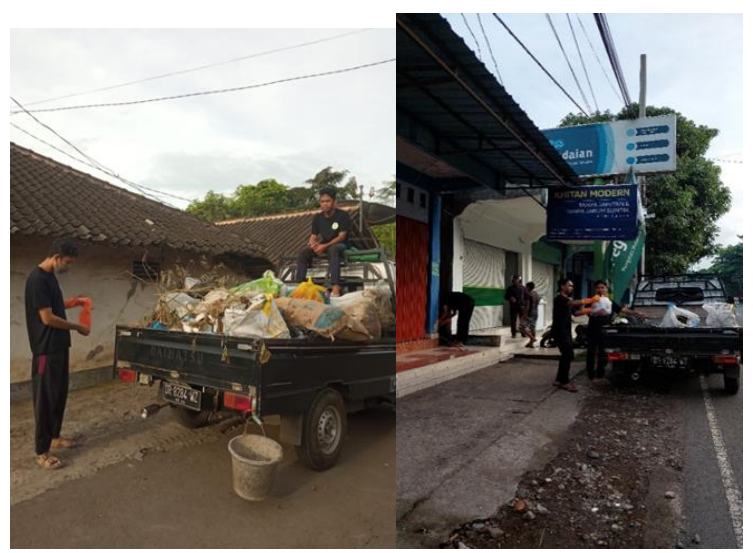

Gambar 9. Pengangkutan sampah setiap hari Sabtu

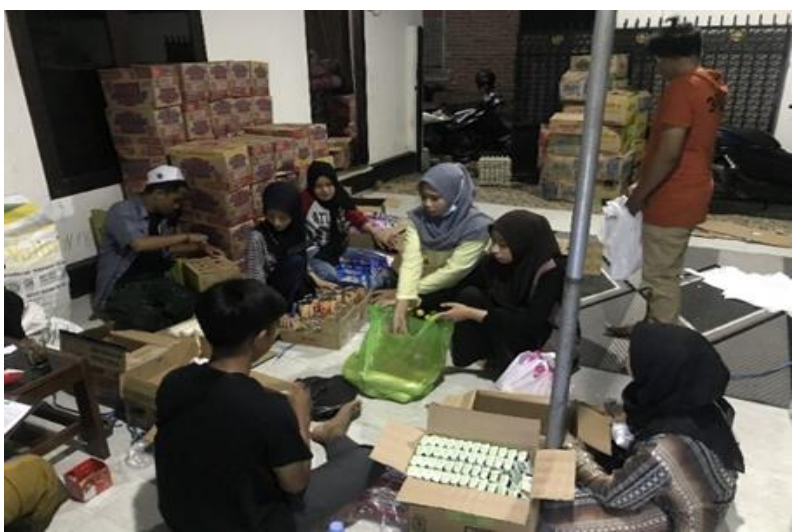

Gambar 10. Mempersiapkan sembako untuk lansia 


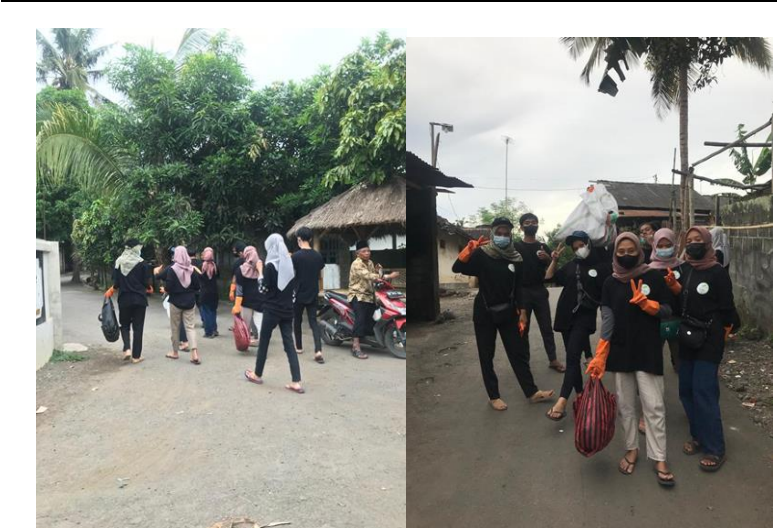

Gambar 11. Membersihkan sampah di pinggir jalan

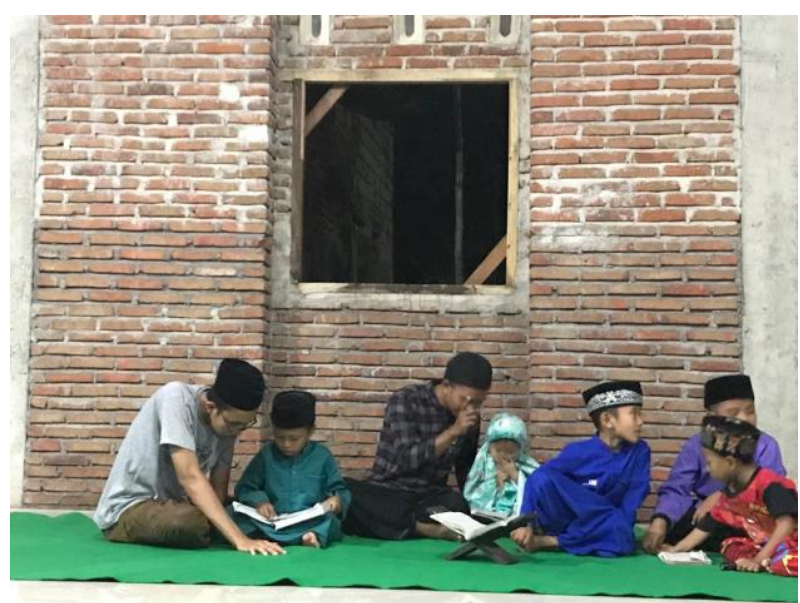

Gambar 12. Mengajar ngaji setiap habis sholat Maghrib

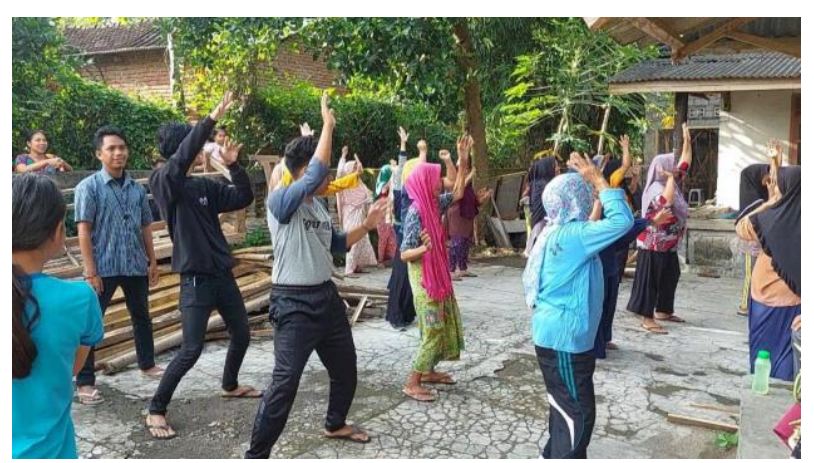

Gambar 13. Mengikuti senam setiap hari Minggu

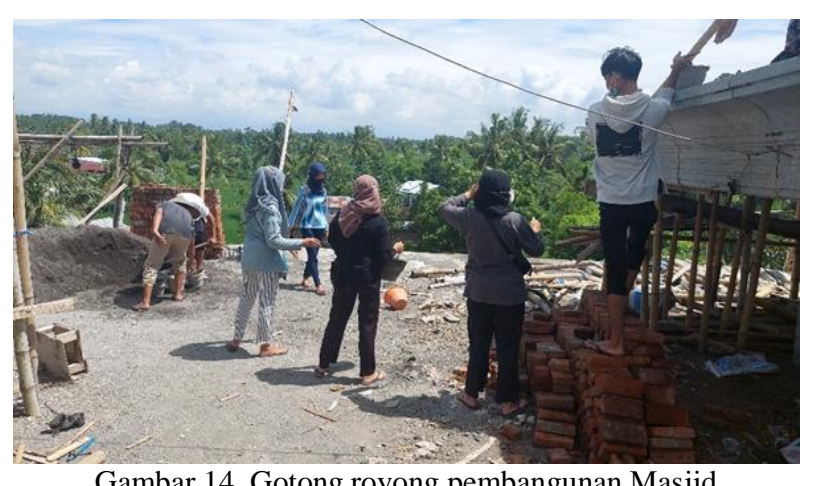

Gambar 14. Gotong royong pembangunan Masjid

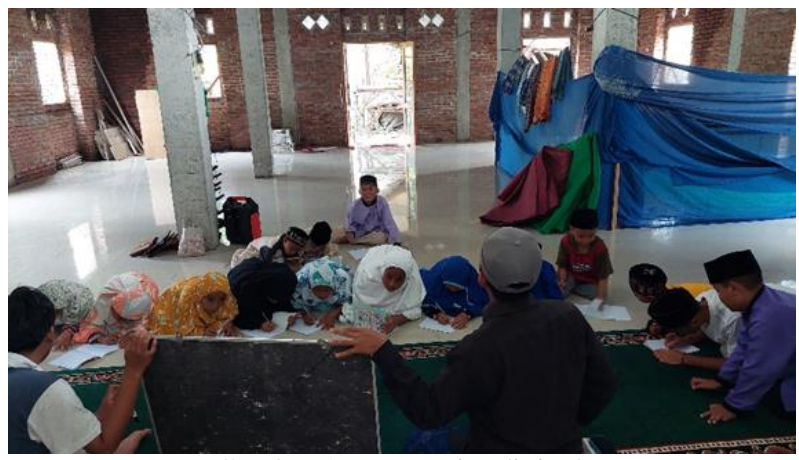

Gambar 15. Mengajar diniyah

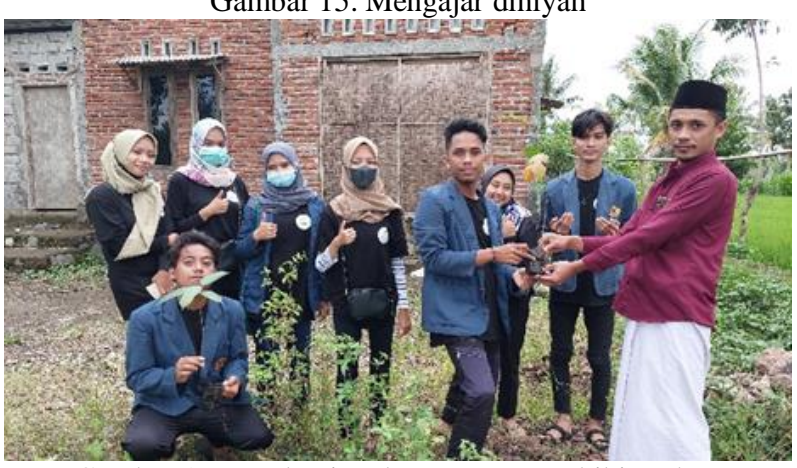

Gambar 16. Pembagian dan penanaman bibit pohon

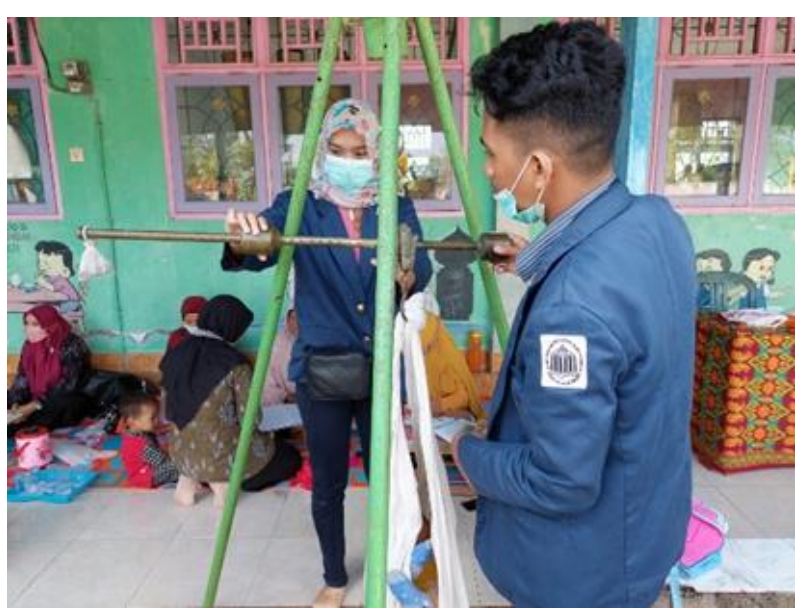

Gambar 17. Membantu kegiatan posyandu

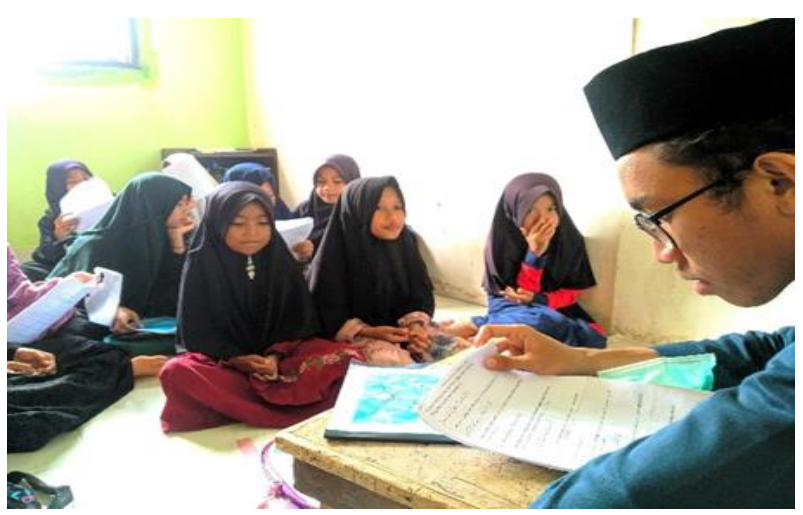

Gambar 18. Mengajar di TPQ Assalam 


\section{Kesimpulan}

Zero waste merupakan upaya penerapan bebas sampah dengan cara mengoptimalisasi pemanfaatan limbah plastik dan limbah rumah tangga yang dapat menjadi ancaman bagi kesehatan, baik manusia, hewan, tumbuhan maupun bumi. Pengolahan sampah yang berbasis zero waste ini di awali dengan melakukan pengumpulan, pemilahan, daur ulang atau penggunaan kembali biasa dikenal dengan prinsip 3R (Reuse, Reduce, Recycle). Berdasarkan dari hasil dan analisis pengolahan sampah Desa Pengadang, maka didapatkan sebagai berikut:

1. Pengolahan sampah rumah tangga (sampah organik) menjadi pupuk kompos dan ecoenzim.

2. Salah satu alternatif pengolahan sampah anorganik menjadi barang yang layak jual dan memiliki nilai ekonomi yaitu pembuatan ecobrick.

\section{Saran}

Program zero waste sebagai salah satu program unggulan pemerintah daerah diharapkan ke depannya dapat terus dilakukan di Desa Pengadang sebagai upaya mengurangi jumlah sampah yang dibuang dan dapat bernilai ekonomis apabila diolah menjadi kerajinan.

\section{Ucapan Terima Kasih}

Terima kasih yang sebesar-besarnya kami ucapkan kepada semua pihak yang terlibat selama program KKN Tematik Zero Waste di Desa Pengadang, Kecamatan Praya Tengah, terutama kepada dosen pembimbing lapangan yakni Bapak Dr. H. NURIADI S.S., M. Hum, Kepala Desa Pengadang yakni Bapak Zainal Abidin serta seluruh jajarannya yang telah memberikan kami perizinan pelaksanaan program ini dan semua mitra kami dalam hal ini masyarakat Desa Pengadang.

\section{Daftar Pustaka}

\section{Karuniastuti, N. (2014). TEKNOLOGI BIOPORI \\ UNTUK MENGURANGI BANJIR DAN TUMPUKAN SAMPAH ORGANIK. Swara Patra, 4(2). Retrieved from http://ejurnal.ppsdmmigas.esdm.go.id/sp/index. php/swarapatra/article/view/76}

Rambe, Titin Rahmayanti. (2021). Sosialisasi dan Aktualisasi Eco-Enzyme Sebagai Alternatif Pengolahan Sampah Organik Berbasis Masyarakat di Lingkungan Perumahan Cluster Pondok II.Jurnal Pengabdian Kepada Masyarakat (JPKM) P-ISSN. 2721-9895 Vol. 2
No.1,
https://jurnal.stkipalmaksum.ac.id/index. 2021. php/jpkm/article/view/147 